\title{
DIRECT SIMPLE SHEAR TESTS ON SNOW AND THEIR RELATION TO SLAB AVALANGHE FORMATION
}

\author{
By David M. McGlung \\ (Norges Geotekniske Institutt, P.O. Box 40, Tåsen, Oslo 8, Norway)
}

\begin{abstract}
Many slab avalanches can be attributed to shear failure in a weak, thin basal layer at the slab base. A reasonable starting point for evaluation of the conditions prior to fracture is, therefore, an investigation of shear failure in thin samples of snow. This paper gives the experimental procedure and data on measurements of shear stress versus displacement for thin samples of snow under plane strain and approximately simple shear conditions. The data are given under varying conditions of strain-rate, normal stress, density and snow type. The results show that the samples exhibited strain-softening provided they were sheared faster than they gained strength by settlement under the chosen conditions. If snow fails at the base of a slab in the way in which it fails in the laboratory, then a mechanism is provided whereby tensile stresses would be produced in the slab and whereby the corresponding maximum principal stresses would be rotated toward a direction parallel to the slope, thereby promoting avalanche release.

RÉsumÉ. Tests simples directs de cisaillement dans la neige et leur relations avec la formation des avalanches de plaque. De nombreuses avalanches de plaque de neige semblent étre dûes à la rupture au cisaillement d'une couche mince basale, de faible résistance, à la base de la plaque de neige. Un point de départ raisonnable pour l'évaluation des conditions qui précèdent une avalanche est donc l'étude de la rupture au cisaillement dans de minces échantillons de neige. Cet article présente la procédure expérimentale et les résultats de mesures de la contrainte de cisaillement en fonction du déplacement dans de minces échantillons de neige pour des conditions de cisaillement simple et de déformation plane. Les résultats sont présentés pour diverses valeurs du taux de déformation, de la contrainte normale, de la densité et du type de neige. Les résultats indiquent que les échantillons exhibent un comportement de ramolissement lorsqu'ils sont cisaillés plus rapidement qu'ils ne gagnent de résistance dû à la consolidation. $\mathrm{Si}$ la neige se rompt à la base d'une plaque de neige comme elle le fait dans le laboratoire, des contraintes de traction sont produites dans la plaque de neige et les contraintes principales maximales correspondantes sont tournées dans la direction parallèle à la pente, favorisant ainsi le déclenchement d'une avalanche.
\end{abstract}

Zusammenfassung. Unmittelbare, einfache Scherversuche an Schnee und ihre Beziehung zur Bildung von SchneebrettLawinen. Viele Schneebrettlawinen scheinen durch ein Scherversagen in einer schwachen, dünnen Schicht am Grunde des Brettes verursacht zu sein. Ein vernünftiger Ausgangspunkt für die Untersuchung der Verhältnisse vor dem Bruch ist deshalb das Studium des Scherversagens in dünnen Schneeproben. Die vorliegende Arbeit gibt das Vorgehen und experimentelle Daten für Messungen der Scherspannung gegenüber der Verlagerung an dünnen Schneeproben unter einfacher Scherung und ebener Spannung. Die Daten beziehen sich auf verschiedene Verformungsraten, Normalspannungen, Dichten und Schneearten. Die Ergebnisse zeigen, dass die Proben unter der Spannung nachgeben, sofern sie schneller geschert werden, als ihre Festigkeit durch Setzung unter den gewählten Verhältnissen zunimmt. Wenn Schnee am Grunde eines Brettes so nachgibt wie im Laborversuch, ergibt sich ein Mechanismus, durch den Zugspannungen im Brett entstehen und die entsprechenden maximalen Hauptspannungen in eine Richtung parallel zur Hangneigung eingedreht würden, wodurch wiederum die Lawine ausgelöst würde.

\section{INTRODUGTION}

Snow stratigraphy studies at the fracture lines of dry slab avalanches often show a relatively hard (often wind-packed) thick slab overlying a thin, weak layer (often termed the sliding layer). An investigation of shear failure in thin samples of snow is a reasonable starting point for the conditions prior to fracture.

This paper gives a procedure and some data for a method for the determination of shear stress versus displacement for thin samples of snow under conditions of plane strain and approximately simple shear. The test variables chosen were close to the expected values for typical slab avalanche conditions. The test results are a basis for an analysis of those situations in which slab avalanche release is expected to be preceded by slow shear failure in the weak layer.

\section{THE DIREGT-SHEAR APPARATUS}

This simple shear apparatus attempts to simulate experimentally the strain conditions in a narrow shear zone between two rigid bodies which move relative to each other. The specimen is uniformly strained in plane strain and approximately simple shear. The specimens are cut 
and mounted such that in situ sample disturbance is kept to a minimum (Landva, I964). The specimens are placed between two perspex caps and surrounded by a wire-reinforced rubber membrane. This arrangement allows thickness changes to occur during the test without any diameter change, thus giving plane strain conditions. Figure I shows the direct simple-shear apparatus.

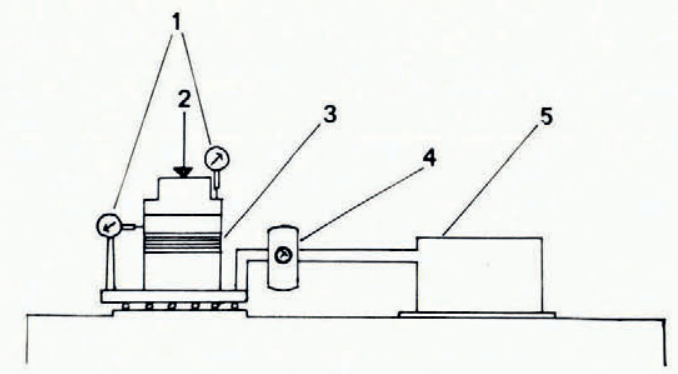

Fig. I. Diagram of direct simple-shear apparatus. I. Dial gauges for measurement of horizontal and vertical displacement. 2. Vertical load applied to a top cap over sample. 3. Sample surrounded by reinforced rubber membrane. 4. Load gauge for horizontal force. 5. Gear box containing exchangeable servogear motor.

The specimen is placed on the bottom plate of the loading frame. The bottom cap is fixed to the bottom plate which guides it during the shearing. The bottom cap is prevented from tilting by specially mounted locking screws. Vertical load is transferred to the fixed cap by a loading rod. The top cap remains fixed and is also prevented from tilting by locking screws.

The horizontal force is applied to the bottom cap by a motor turning at a constant rate which, working through a variable-speed gear box, turns a thrust screw. The values of horizontal force are determined from the deformation of a calibrated proving ring. A uniform specimen strain is obtained because the specimens are relatively thin, and because they are confined in the rubber membrane. The apparatus controls the strain conditions leaving the direction and magnitude of the principal stresses unknown. As the shear stress increases in the horizontal plane, a continuous rotation and change in the magnitude of the principal stresses will result.

The interpretation of the tests is limited to conditions in a narrow shear zone separating two bodies which move relative to each other. Failure is expected when the shear stress on the horizontal plane shows a peak. The samples are sheared smoothly and evenly without recognizable fracture or cracking. The specimen is still in one piece at the end of the test.

\section{EXPERIMENTAL PROGEDURE}

The experiments described here were performed in the cold laboratory of the avalanche research station of Norges Geotekniske Institutt in western Norway. All of the specimens were taken from near the surface of the snow-pack. The specimens were oriented in the apparatus as they were oriented in the snow-pack, parallel to the snow layers and the snow surface. At the beginning of each test, the snow specimen was carefully consolidated by applying normal loads in steps to the loading rod. The amount of consolidation prior to shearing was determined by measuring thickness changes with a dial gauge. Since snow settles continuously under a load, the samples were consolidated by arbitrary amounts of from $0.5 \%$ to $16.9 \%$ of the sample thickness. Initial sample thicknesses were from 16.0 to $18.5 \mathrm{~mm}$. The sample diameter was I $5 \mathrm{~mm}$ for all tests. 
After consolidation a shear test was performed by applying a horizontal load to the specimen with the motor running at a constant displacement rate. Three different displacement rates were used corresponding to three different ranges of expected time-to-failure in the field. Measurements of horizontal displacement, vertical displacement and applied horizontal load were recorded throughout the experiments.

\section{RESUlts OF TESTS}

These tests were performed under conditions close to those expected for field conditions just before slab avalanche release. Accordingly, the variables studied were chosen from the expected ranges shown by profile investigations of the fracture line in dry slab avalanches carried out by Roch (1966) and Perla (unpublished). The parameters varied included the following:

I. Snow densities in the range $150 \mathrm{~kg} \mathrm{~m}^{-3}$ to $400 \mathrm{~kg} \mathrm{~m}^{-3}$.

2. Applied normal stresses in the range of o.o I to o. I bar.

3. Three rates of displacement. The rates were $8.95 \mathrm{~mm} \mathrm{~h}^{-1}, 0.73 \mathrm{~mm} \mathrm{~h}^{-1}$, and 0.13 $\mathrm{mm} \mathrm{h}^{-1}$. These displacement rates resulted in sample failures for times of the order of $0.25 \mathrm{~h}, 3 \mathrm{~h}$, and $15 \mathrm{~h}$ respectively. The maturation time for slab avalanches is not precisely known, but field experience indicates that the times chosen here should span the time of interest for natural slab release.

4. Test temperatures in the range $-6^{\circ} \mathrm{C}$ to $-10^{\circ} \mathrm{C}$ corresponding to typical values for diry slab avalanche conditions. It was hoped to eliminate the effect of temperature variation on the tests by confining the tests to this narrow range.

5. Other parameters recorded included the in situ hardness estimated by the Swiss method (Schaefer and others, [1952]) and the crystal type as given by Sommerfeld and LaChapelle (1970). The mean crystal diameter was estimated by examining the sample on a millimeter rectile under a microscope.

Table I lists the measured parameters for 34 test results. Samples which were cut from the same block of snow and which could be regarded as similar are enclosed in brackets on the left-hand side of Table I. For those experiments in which the peak stress was not reached during the test, values in the peak stress column are preceded by $>$. For those tests in which a peak stress was reached, but for which the stress was still dropping when the limit of travel of the apparatus was reached, the values in the residual stress column are preceded by $<$. The distance of travel for the bottom cap is limited to approximately $6 \mathrm{~mm}$. It is only because the snows tested were of a somewhat brittle character that the residual strength could be estimated by the direct shear tests. The seventh column in Table I gives a characteristic horizontal displacement at which the residual strength was reached. For those samples in which the residual strength was not reached, the values are preceded by the sign $>$. The values for consolidation prior to testing are given as percentages of the sample heights. Initial sample heights were all from $\mathrm{I} 6.0$ to $18.5 \mathrm{~mm}$. The in situ hardnesses are given according to the Swiss numbering system (Schaefer and others, [1952]). Approximate values for the ram resistance are: 0-19.6 N (o-2 kg), I9.6-147 N (2-15 kg), 147-490 N (15-50 kg), 490-980 N (50-100 $\mathrm{kg}$ ) for hardnesses $\mathrm{I}-4$ respectively. Test temperatures are given as the average throughout the test since the cold laboratory in which the tests were run was subject to minor variations.

\section{Discussion OF RESULTS}

These results were obtained with the study and simulation of shear failure in a thin layer of snow at the base of a slab avalanche in mind. Therefore, it seems that the results will be most useful in any formulation of boundary conditions at the base of snow slabs. Accordingly, the results are reported here in terms of shear stress versus displacement. 
Table I. Parameters derived from the tests on the specimens

\begin{tabular}{|c|c|c|c|c|c|c|c|c|c|c|c|}
\hline $\begin{array}{c}\text { Sample } \\
\text { No. }\end{array}$ & $\begin{array}{c}\text { Peak } \\
\text { stress } \\
\text { bar }\end{array}$ & $\begin{array}{c}\text { Residual } \\
\text { stress } \\
\text { bar }\end{array}$ & $\begin{array}{c}\text { Normal } \\
\text { stress } \\
\text { bar }\end{array}$ & $\begin{array}{c}\text { Hori- } \\
\text { zontal } \\
\text { displace- } \\
\text { ment } \\
\text { speed } \\
\mathrm{mm} / \mathrm{h}\end{array}$ & $\begin{array}{l}\text { In situ } \\
\text { hardness }\end{array}$ & $\begin{array}{c}\text { Displace- } \\
\text { ment } \\
a t \\
\text { residual } \\
\text { stress } \\
\mathrm{mm}\end{array}$ & $\begin{array}{l}\text { Final } \\
\text { density } \\
\mathrm{kg} / \mathrm{m}^{3}\end{array}$ & $\begin{array}{l}\text { Consoli- } \\
\text { dation } \\
(\% \text { of } \\
\text { height })\end{array}$ & $\begin{array}{c}\text { Crystal } \\
\text { type }\end{array}$ & $\begin{array}{c}\text { Crystal } \\
\text { diameter } \\
\mathrm{mm}\end{array}$ & $\begin{array}{c}\text { Test } \\
\text { tempera- } \\
\text { ture } \\
{ }^{\circ} \mathrm{C}\end{array}$ \\
\hline I & $>0.064$ & - & 0.028 & 0.73 & I & $>4.6$ & 210 & 8.2 & II.A. I & I.o & -6 \\
\hline 2 & $>0.035$ & - & 0.009 & 0.73 & I & $>4.9$ & 170 & $4 \cdot 5$ & II.A.I & 1.0 & -6 \\
\hline 3 & 0.099 & $<0.03^{2}$ & $0.03^{8}$ & 0.73 & $3-4$ & $>4.5$ & 240 & I. 8 & II.B.I & 0.3 & -6 \\
\hline 4 & $>0.045$ & - & 0.014 & 0.73 & $2-3$ & $>4.7$ & 200 & 3.5 & II.A. 2 & 1.3 & -8 \\
\hline 5 & 0.096 & 0.078 & $0.03^{8}$ & 0.13 & 4 & 4.6 & 380 & I. 7 & II.B.I & 0.2 & -7 \\
\hline 6 & 0.094 & 0.071 & 0.038 & 0.73 & 4 & 3.5 & 390 & 1.6 & II.B.I & 0.2 & -7 \\
\hline 7 & 0.117 & 0.082 & 0.038 & 0.73 & 3 & 6.4 & 250 & I.I & II.A.2 & 0.8 & -8 \\
\hline 8 & 0.009 & $<0.019$ & 0.038 & 0.13 & 3 & $>5.9$ & 260 & 0.9 & II.A.2 & 0.4 & -8 \\
\hline 9 & 0.101 & 0.072 & 0.038 & 0.73 & 3 & 3.7 & 380 & I. 3 & II.B.I & 0.2 & -8 \\
\hline 10 & $0.05^{2}$ & 0.030 & 0.019 & 0.73 & 3 & 2.5 & 390 & 0.5 & II.B. I & 0.2 & -8 \\
\hline II & $0.09 \mathrm{I}$ & $<0.047$ & 0.056 & 0.73 & 3 & $>5.9$ & 390 & 2.5 & II.B.I & 0.2 & -8 \\
\hline 12 & 0.147 & 0.099 & 0.076 & 0.73 & 3 & 2.8 & 390 & 2.0 & II.B. I & 0.2 & -8 \\
\hline 13 & 0.214 & $<0.098$ & 0.113 & 0.73 & 3 & $>5.0$ & 380 & $4 \cdot 1$ & II.B. I & 0.2 & -7 \\
\hline 14 & 0.137 & 0.101 & 0.056 & 0.73 & 3 & 4.9 & 350 & 2.0 & II.B.I & 0.2 & -7 \\
\hline 15 & 0.087 & $<0.029$ & 0.028 & 0.73 & 2 & $>4.7$ & 300 & 1.5 & II.B. I & 0.3 & -7 \\
\hline 16 & 0.104 & $0.06_{3}$ & 0.028 & 8.95 & 2 & 5.4 & 260 & 3.2 & II.B.I & 0.3 & -7 \\
\hline 17 & 0.119 & $<0.047$ & $0.03^{8}$ & 0.73 & 2 & $>5.5$ & 370 & I. 4 & II.B.I & 0.2 & -9 \\
\hline 18 & 0.140 & 0.087 & 0.038 & 8.95 & 2 & 3.4 & 300 & 3.0 & II.B.I & 0.2 & $\begin{array}{l}9 \\
-9\end{array}$ \\
\hline I9 & 0.102 & $<0.066$ & 0.028 & 0.73 & 2 & $>7.2$ & 310 & I. I & II.B.I & 0.3 & -7 \\
\hline 20 & 0.092 & 0.065 & 0.028 & 8.9 & 2 & 3.1 & 310 & I. 3 & II.B. I & 0.3 & -7 \\
\hline $2 \mathrm{I}$ & 0.070 & $0.05^{2}$ & 0.019 & 8.9 & I & 4.5 & 180 & 6.2 & I.B. & I.O & -9 \\
\hline 22 & $>0.075$ & - & 0.019 & 0.73 & I & $>6.7$ & 180 & 4.5 & I.B. & I.O & -6 \\
\hline 23 & 0.073 & 0.060 & 0.019 & 8.95 & I & $4 \cdot 3$ & 170 & 2.9 & I.B. & 1.0 & -10 \\
\hline 24 & $>0.058$ & - & 0.019 & 0.73 & I & $>6.6$ & 190 & 3.8 & I.B. & 1.0 & -7 \\
\hline 25 & 0.097 & $<0.092$ & $0.03^{8}$ & 0.73 & 2 & $>6.5$ & 330 & I. 7 & II.B. I & 0.2 & -6 \\
\hline 26 & 0.112 & $0.0 \breve{6}_{4}$ & olo38 & 8.9 & 2 & 2.6 & & 2.5 & II.B.I & 0.2 & -10 \\
\hline 27 & 0.109 & $0.05^{8}$ & 0.019 & 0.73 & 3 & $5 \cdot 5$ & & 3.6 & II.B.I & 0.4 & -8 \\
\hline 28 & 0.147 & $<0.124$ & $0.03^{8}$ & 0.73 & 3 & $>7.1$ & 280 & 9.8 & I.B & 0.3 & -8 \\
\hline 29 & 0.152 & 0.126 & $0.03^{8}$ & 0.7 & 3 & 5.6 & 280 & 6.5 & II.B.I & 0.2 & -9 \\
\hline 30 & 0.068 & 0.049 & 0.019 & 0.73 & 3 & 3.4 & 260 & 1.7 & & 0.2 & -9 \\
\hline $3^{I}$ & 0.023 & $<0.014$ & $0.03^{8}$ & 0.13 & $2-3$ & I. 4 & 200 & 16.9 & II.B. I & 0.2 & -9 \\
\hline 32 & $>0.011$ & - & 0.019 & 0.13 & I & $>1.5$ & 150 & 7.2 & II.A.I & 0.8 & $\begin{array}{r}9 \\
-9\end{array}$ \\
\hline 33 & $>0.054$ & - & 0.019 & 0.73 & I & $>5.8$ & 150 & 9.6 & II.A. I & 0.8 & -9 \\
\hline 34 & 0.037 & $<0.020$ & 0.009 & 0.73 & I & $>6.7$ & 150 & 3.4 & II.A.I & 0.8 & -9 \\
\hline
\end{tabular}

The results fall into two basic categories: (I) samples in the low density range which had a very soft in situ hardness and which were strained at the two slowest rates, and (2) low density, very soft snow samples strained at the fastest rate together with the remainder of the samples.

Category I tests showed shear stress which continuously increased with horizontal displacement throughout the tests so that no definite failure level could be defined; the samples exhibited strain hardening. Measurements of vertical displacement showed that these samples settled vertically throughout the tests. Figure 2 shows an example of the data from one of these tests. Category 2 tests exhibited strain softening. In these tests the shear stress rose until a peak strength was reached at a characteristic displacement. Further displacement then showed a gradual loss of shear resistance until a residual shear stress was reached after which the stress remained roughly constant with displacement. Measurements of vertical displacement showed that the samples dilated after an initial settling which persisted until the peak stress was reached, approximately. Figure 3 shows typical results from one of the samples exhibiting strain softening.

\section{Effect of normal stress}

Figure 4 shows peak and residual strengths plotted against normal stress for fine-grained wind-packed samples cut from the same block of snow. The variation in density is about $12 \%$. 


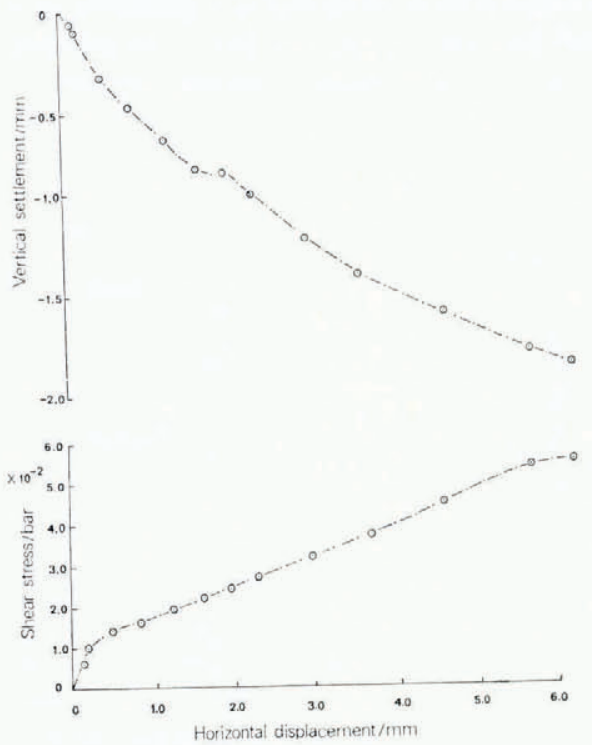

Fig. 2. Typical curves of shear stress versus horizontal displacement and vertical displacement versus horizontal displacement for a sample exhibiting strain hardening (sample number 33). Snow properties and test conditions are listed in Table I.

In this case, the results show that both the peak strength and residual strength increase with normal pressure in the important low-stress range. In the example shown here the residual strength reached a maximum and levelled out at a characteristic normal stress. It is not at present known whether these results are general or particular. Similar tests on clay usually show both peak and residual stress increasing with normal stress. More tests need to be done before a general statement can be made. It should be noted that the snow used in this set of

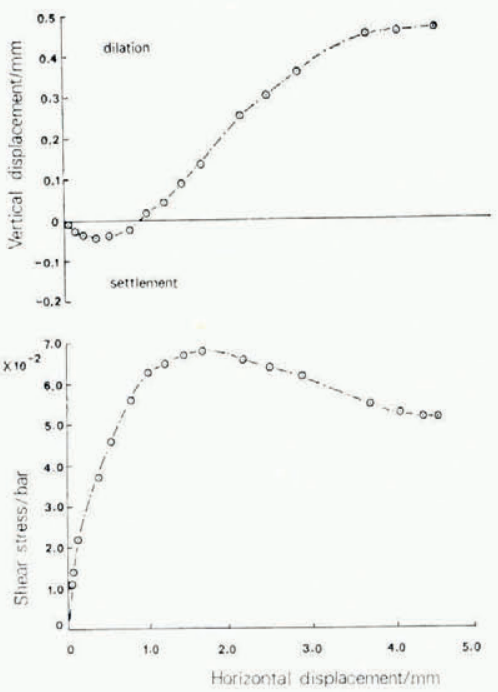

Fig. 3. Typical curves of shear stress versus horizontal displacement and vertical displacement versus horizontal displacement for a sample exhibiting strain softening (sample number $3^{\circ}$ ). Snow properties and test conditions are listed in Table I. 
experiments would not ordinarily be considered as a possible snow type for a weak layer in a dry slab avalanche. In addition, the results are here complicated by the fact that more preconsolidation was used in the tests with higher normal stresses.

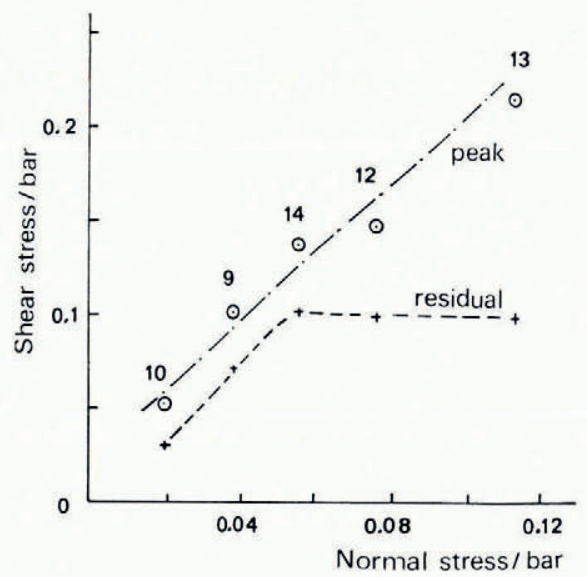

Fig. 4. Estimates of peak shear stress and residual shear stress versus applied normal stress for a group of similar samples. (The numbers near the "peak" data points indicate the sample number.)

\section{Effect of rate of loading}

Perhaps the most interesting aspects of these experiments are the effects on the results of changes in the rate of loading. This effect was investigated for 9 different sample pairs for 3 different testing speeds. For those samples tested at the two slower rates of loading which were of low density and very soft in situ hardness, strain hardening was observed. However, when similar samples were tested at the fastest rate of strain, the samples exhibited strain softening. Figure 5 shows curves from one such sample pair.

These results are consistent with the idea that the horizontal displacement to failure depends upon the rate of displacement. If a sample is of low enough density and soft enough,

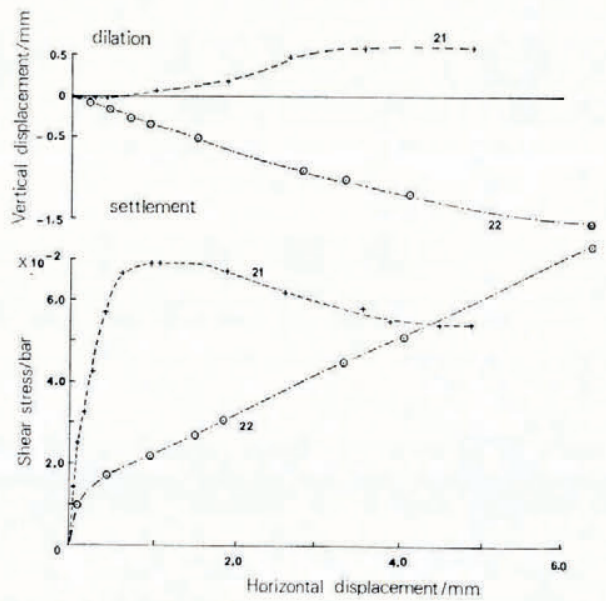

Fig. 5. Shear stress versus horizontal displacement and vertical displacement versus horizontal displacement for two similar samples of low density and very soft in situ hardness sheared at different rates. (Numbers near the curves indicate the sample
number.) 
it is possible that it can gain strength by settling at a rate faster than that at which the horizontal load is being applied. However, if a similar sample is sheared faster, it reaches a peak strength and softens if not enough time is allowed for it to gain strength by settling. The data in Table I clearly show the effect of loading rate on the horizontal displacement at which the residual strength is reached in the softer samples. The experimental apparatus allowed about $6 \mathrm{~mm}$ of displacement. It is possible that very soft snow of low density would soften at the low loading rate on further displacement. We can say nothing about this.

\section{Shear strength as a function of density}

The data presented here are from samples in the density range from $150 \mathrm{~kg} \mathrm{~m}^{-3}$ to 400 $\mathrm{kg} \mathrm{m}^{-3}$ at different normal stresses and loading rates. Due to the limited number of tests, it is not possible to make a definite statement about strength as a function of density. From Table I, there is a group of $\mathrm{I} 3$ samples at a normal stress of 0.04 bar which show peak strengths of from 0.02 bar to 0.15 bar in the density range $26 \mathrm{og} \mathrm{m}^{-3}$ to $280 \mathrm{~kg} \mathrm{~m}^{-3}$ for different rates of strain. The lowest strength might have been due to sample damage or the high amount of pre-consolidation. If that point is eliminated, the scatter band is very much narrower. It seems reasonable that the peak strength is a function of the bond strength between crystals which might not be directly correlated with density in the range presented in Table I.

\section{Effect of hardness, grain size and type, and temperature}

The data show that hardness affects the shear properties of snow. The curves of stress versus horizontal displacement and vertical displacement versus horizontal displacement depend on hardness under the loading conditions chosen. A harder sample will display very little settlement prior to reaching the peak strength and it will display a shorter characteristic displacement at which the residual strength is reached. This effect is particularly striking when the results for soft versus hard samples are compared (compare Figs 2 and 3, for example). A very soft sample appears harder or more brittle if sheared faster (Fig. 5).

Insufficient data are available to make a statement about the relationship of the tests to crystal size and type or temperature in the experiments. The temperature regime was deliberately kept narrow to minimize the effects of temperature changes on the results.

\section{INTERPRETATION OF RESULTS}

For those situations in which shear failure in a thin weak layer is expected as the cause of avalanche release, the main purpose behind a formulation of boundary-value problems is the establishment of consistent relationships between shear stress and displacement. It is unlikely that it will be possible to formulate a boundary condition wholly in terms of displacements or stresses. The main result of this paper has been that snow is a strain-softening material displaying consistent stress-displacement relations, but that the relationships are complicated. As with similar studies in soil mechanics (Bjerrum, 1973), it is convenient to regard the shear strength of snow as having two components: (I) cohesive and (2) frictional. Experiments have shown that, when a sample of snow is sheared, the shear stress reaches a peak after a relatively short displacement and thereafter drops continually until a residual stress value is reached at a larger characteristic displacement. It is convenient to view the first part of the curve as the mobilization of a cohesive component at a small displacement. According to this hypothesis, mobilization of the frictional component would require a larger displacement, and would be accompanied by volume changes during a re-arrangement of the structure. The frictional component would be associated with the residual strength. 
It should be pointed out that volume changes were observed throughout all of the tests so that at no time was the deformation strictly elastic. However, the volume changes were usually small until the peak strength was reached. If the experiments are interpreted in terms of plasticity theory the residual strength would represent the resistance to shear along a plastic slip line which had developed fully.

The data clearly show the effects of rate of loading and in situ hardness on the characteristic horizontal displacements when peak and residual stresses are attained. Harder samples, or soft samples which are strained quickly, display shorter characteristic displacement at failure and hence appear more brittle in a relative sense in that they exhibit less plastic deformation prior to failure.

\section{Relation to slab avalanche release}

If strain softening occurs in snow in a weak layer at the base of a snow slab, slab avalanche release will be promoted. Figure 6 depicts a schematic of a snow slab underlain by a layer which has undergone strain softening over a certain region. There are two effects which will produce tensile stresses in the slab down-slope from the edge of the region where the softening is presently occurring. The first of these is the stress concentration due to the change in boundary conditions as the stress falls from peak to residual over a characteristic distance. The second effect is due to the reduction in basal shear stress from gravitational body-weight stress to the residual value outside the region where the softening is taking place. Both of these effects would, in general, work to increase the tensile stresses in the body of the slab and, thus, promote tensile fracture.

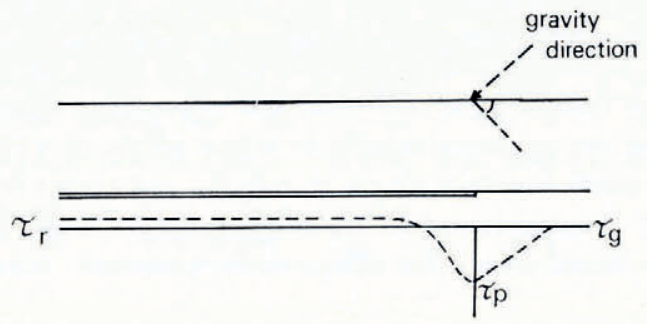

Fig. 6. Schematic of the basal shear stress conditions as a function of distance for a mature slab avalanche with a weak layer exhibiting strain softening. Gravitational body shear stress, peak shear stress and residual shear stress are denoted by $\tau_{\mathrm{g}}, \tau_{\mathrm{p}}, \tau_{\mathrm{r}}$.

Data from profiles of avalanche fracture lines (Roch, I966; Perla, unpublished) consistently show failures at body-weight stresses less than values of shear strength measured in the field with shear frames. If shear frames measure closer to the peak strength than the residual strength, strain softening can provide a partial explanation of the measured field data at avalanche fracture lines because the peak strength would be expected to exceed basal bodyweight shear stresses (Fig. 6). However, there is likely to be an important size effect associated with the measured strengths, that is, decreasing measured strength with increasing sample size.

\section{Acknowledgements}

I am indebted to Mr T. Berre and Dr J. H. Prévost of the Norges Geotekniske Institutt for many useful discussions regarding this work. 


\section{REFERENGES}

Berre, T., and Bjerrum, L. 1973. Shear strength of normally consolidated clays. Proceedings of the eighth International Conference on Soil Mechanics and Foundation Engineering, Moscow, Vol. I.1, p. 39-49.

Bishop, A. W. 1966. Strength of soils as engineering materials. Géotechnique (London), Vol. 16, No. 2, p. 89-1 30.

Bjerrum, L. 1967. Progressive failure in slopes of overconsolidated plastic clay and clay shales. Fournal of the Soil Mechanics and Foundations Division, American Society of Civil Engineers, Vol. 93, No. SM5, p. I-49.

Bjerrum, L. 1973. Problems of soil mechanics and construction on soft clays. Proceedings of the eighth International Conference on Soil Mechanics and Foundation Engineering, Moscow, Vol. 1.3, p. 1 I 1 -59.

Bjerrum, L., and Landva, A. I966. Direct simple-shear tests on a Norwegian quick clay. Géotechnique (London), Vol. 16 , No. i, p. 1-20.

Canada. National Research Council. 1954. The International Classification for Snow (with special reference to snow on the ground), issued by Commission on Snow and Ice of the International Association of Hydrology. Canada. National Research Council. Associate Committee on Soil and Snow Mechanics. Technical Memorandum No. 31 .

Haefeli, R. 1951. Investigation of the shear strengths of saturated cohesive soils. Géotechnique (London), Vol. 2, No. 3 , p. $186-208$.

Landva, A. 1964. Equipment for cutting and mounting undisturbed specimens of clay in testing devices. Norwegian Geotechnical Institute. Internal Report F. 175.

Perla, R. I. [1975.] Stress and fracture of snow slabs. [Union Géodésique et Géophysique Internationale. Association Internationale des Sciences Hydrologiques. Commission des. Neiges et Glaces.] Symposium. Mécanique de la Neige. Actes du colloque de Grindelwald, avril 1974, p. 208-21. (IAHS-AISH Publication No. 1 14. .)

Perla, R. I. Unpublished. The slab avalanche. [Ph.D. thesis, University of Utah, I971.]

Roch, A. 1966. Les déclenchements d'avalanches. Union de Géodésie et Géophysique Internationale. Association Internationale d'Hydrologie Scientifique. Commission pour la Neige et la Glace. Division Neige Saisonnière et Avalanches. Symposium international sur les aspects scientifiques des avalanches de neige, 5-10 avril 1965, Davos, Suisse, p.182-95. (Publication No. 69 de l'Association Internationale d'Hydrologie Scientifique.)

Schaefer, V. J., and others. [1952.] Entwurf einer internationalen Schneeklassifikation ausgearbeitet durch das Komitee für Schneeklassifikation, von V. J. Schaefer, G. J. Klein, M. R. de Quervain. Union Géodésique et Géophysique Internationale. Association Internationale d'Hydrologie Scientifique. Assemblée générale de Bruxelles, 1951. Tom. I, p. 129-41. (Publication No. 32 de l'Association Internationale d'Hydrologie.)

Sommerfeld, R. A., and LaChapelle, E. R. 1970. The classification of snow metamorphism. Fournal of Glaciology, Vol. 9, No. 55, p. 3-17.

Sommerfeld, R. A., and others. 1976. A correction factor for Roch's stability index of slab avalanche release, by R. A. Sommerfeld, R. M. King and F. Budding. Journal of Glaciology, Vol. 17, No. 75, p. 145-47.

\section{DISGUSSION}

R. L. BROWN: In your experimental program, what was the magnitude of the shear strains incurred?

D. M. McClung: The shear strains at the completion of the tests were $25 \%-30 \%$.

R. A. Sommerfeld: What were your densities and strain-rates?

McClung: Specimens were tested in the density range of ${ }_{1} 5^{0} \mathrm{~kg} \mathrm{~m}^{-3}$ to $400 \mathrm{~kg} \mathrm{~m}^{-3}$. The strain-rates ranged from approximately $2 \% \mathrm{~h}^{-1}$ to $25 \% \mathrm{~h}^{-1}$.

SOMMERFELD: Do you have an estimate of the down-slope distance over which the maximum stress gives to the residual stress?

McClung: Preliminary estimates of the size effect implied by specifying a strain-softening stress-displacement relation as a basal boundary condition indicate that the distance over which the stress drops from peak to residual is on the order of a slab thickness.

P. R. KRY: Have any structural studies been made, through thin sections or any other method, to study the physical mechanisms of strain-hardening or softening in terms of changes in the structural parameters, for example, snow-grain bonding?

MaClung: No.

A. Dyunin: Did you take into account the scale effect of your experiment, i.e. that the size of cylinder might have an influence on the results?

MaClung : No, the effect of sample size has not been studied yet, although I expect that it will be important and that larger samples will show weaker strength values. 